\title{
Expression profile of growth hormone receptor (GHR), insulin like growth factor receptor (IGFR) and leptin genes, with associated blood bio-chemicals and endocrines profiles in black Bengal kids (Capra hircus) during different stages of pre-pubertal growth
}

\author{
Shagufta Perveen ${ }^{1}$, Pradip K. Das ${ }^{1 *}$, Prabal R. Ghosh ${ }^{1}$, Dipak Banerjee ${ }^{1}$, \\ Joydip Mukherjee ${ }^{1}$, and Mohan Mondal ${ }^{2}$ \\ ${ }^{1}$ Department of Veterinary Physiology, West Bengal University of Animal and Fishery Sciences, K. B. Sarani, \\ Kolkata, West Bengal, India \\ ${ }^{2}$ ICAR-National Dairy Research Institute (ERS), Kalyani, Nadia, India
}

PERVEEN, S., P. K. DAS, P. R. GHOSH, D. BANERJEE, J. MUKHERJEE, M. MONDAL: Expression profile of growth hormone receptor (GHR), insulin like growth factor receptor (IGFR) and leptin genes, with associated blood bio-chemicals and endocrines profiles in black Bengal kids (Capra hircus) during different stages of pre-pubertal growth. Vet. arhiv 90, 243-254, 2020.

\section{ABSTRACT}

The aim of this study was to evaluate the expression profile of growth hormone receptor (GHR), insulin like growth factor receptor (IGFR) and leptin genes, together with some blood biochemical (glucose, aspartate aminotransferase, AST; alanine aminotransferase, ALT) and endocrine (growth hormone and cortisol) parameters. For this purpose, blood samples were collected from 25 male and 25 female kids of the Black Bengal goat (Capra hircus), at days 15, 30, 60, 90, 120 and 150. Male kids gained more body weight compared to females. The glucose and cortisol levels significantly $(\mathrm{P} \leq 0.01)$ decreased with the advancement of age. AST, ALT, and growth hormone increased significantly $(\mathrm{P} \leq 0.01)$. In both sexes, plasma glucose level was negatively $(\mathrm{P} \leq 0.01)$ correlated with AST. In males both cortisol and GH levels were positively $(\mathrm{P} \leq 0.05)$ correlated with plasma glucose levels. In female kids only GH showed a positive $(\mathrm{P} \leq 0.05)$ correlation with glucose levels. Female kids had greater expression of the GH receptor, IGFR mRNA and Leptin mRNA on day $30(\mathrm{P} \leq 0.05)$ and day $150(\mathrm{P} \leq 0.01)$. GHR was only positively $(\mathrm{P} \leq 0.05)$ correlated with IGFR and LEP in female kids. On the basis of the results obtained from our research, we are able to conclude that the lower growth rate in female kids expressed more leptin, which stimulated the somatotrophic axis for the expression of GHR and IGFR during the prepubertal growth stage.

Key words: black Bengal goats; growth hormone receptor; IGF receptor; leptin genes; prepubertal growth

\section{Introduction}

India ranks second in terms of its goat population (133.0 million) after China (188.0 million) in the world (FAOSTAT, 2014) along with being largest exporter of sheep \& goat meat to the world
(APEDA, 2018). Black Bengal goats (colloquially Bengal goats) are one of the best goat breeds of India and known globally for their high prolificacy and good quality of meat and hide (DIXIT and

\footnotetext{
*Corresponding author:

Pradip Kumar Das, MVSc, PhD, Professor, Department of Veterinary Physiology, West Bengal University of Animal and Fishery Sciences, 37, K B Sarani, Kolkata - 700037, West Bengal, India, Phone: +91 94326 42502; E-mail: pkdaskol@rediffmail.com
} 
SHUKLA, 1995) despite its slower growth rate, low milk production and higher kid mortality (HUSSAIN et al., 1997; AMIN et al., 2001). As Black Bengal goats are reared primarily for meat production, their prolificacy and growth are the two important economic factors. The prolificacy of black Bengal goats has been well validated with the Polymorphism of fecundity genes (POLLEY et al., 2009) but the studies on growth have mainly focused on the polymorphisms of growth hormone, growth hormone receptor genes and insulin like growth factor genes, and their effects on growth traits in goats (AN et al., 2011; RASOULI et al., 2017) as a whole and black Bengal goats in particular (GUPTA et al., 2007). However, the literature is scant on the alterations in these gene expression patterns throughout the pre-pubertal growth stage, particularly in black Bengal goats. The somatotropic axis, consisting of the growth hormone $(\mathrm{GH})$ and insulin-like growth factors (IGF), governs growth homeostasis in conjugation with other endocrine factors (leptin, glucocorticoids) (PADGETT and GLASER., 2003; KEOGH et al., 2015; AFSAL and SEJIAN, 2018). Leptin is a suitable biomarker from the somatotrophic axis for nutritional stress tolerance in goats (HYDER et al., 2013), and is required for maintaining physiological normalcy (ZIEBA et al., 2005), and the interrelationship between GH, IGF and leptin during the pre-pubertal phase of growth may reveal the growth homeostasis in a comprehensive manner in black Bengal goats. Therefore, the present investigation was designed to explore the expression profile of GHR, IGFR, leptin receptor throughout the pre-pubertal growth phase in male and female black Bengal kids, in relation to some blood biochemical parameters (glucose, plasma AST, ALT) as markers for hepatic functions and endocrine parameters related to growth $(\mathrm{GH}$ and cortisol).

\section{Materials and methods}

Study area and period. The study was carried out at Eastern Regional Station-Indian Veterinary Research Institute, Kalyani Goat Farm of Nadia district, West Bengal, India. The farm is located at an altitude of 11 meters above the mean sea level, at a latitude of $22^{\circ} 98^{\prime} \mathrm{N}$ and at a longitude of $88^{\circ} 44^{\prime} \mathrm{E}$.
It is in the lower Gangetic Plain Region of India. The soil is loamy pattern clay with $\mathrm{pH}$ varying from 6.5 to 8.75 . The environmental temperature was $38.79 \pm 3.44{ }^{\circ} \mathrm{C}$ in summer and $14.98 \pm 4.64{ }^{\circ} \mathrm{C}$ in winter. Relative humidity was $64.36 \%$ and $57.86 \%$ in summer and winter respectively.

Selection of experimental animals and sampling. Thirty clinically healthy pregnant does of the black Bengal goat breed were randomly selected with parity of $4-6(4.38 \pm 0.12)$. The age of the does was recorded as $38.67 \pm 6.48$ Mo with body weight of $21.13 \pm 2.89 \mathrm{Kg}$. The experimental animals were kept in dry, clean and well-ventilated hygienic sheds with a concrete floor. The litter size of the does was recorded as $2.14 \pm 0.04$. In this study, 25 male and 25 female kids were selected randomly from the chosen does. The mean birth weights of the experimental kids were $1.23 \pm 0.11 \mathrm{Kg}$ (males) and $0.92 \pm 0.05$ (females) respectively. All kids were fed with mother's milk up to weaning and were maintained under a free range rearing system. The vaccination and deworming schedules followed in the experimental animals were as per the standard schedule. Each animal was turned out for natural grazing at 8.00 am to $12.30 \mathrm{pm}$, and again at 2.30 $\mathrm{pm}$ to $5.30 \mathrm{pm}$. No extra concentrated feed was provided at the shelter. Animals were provided with adequate quantities of clean and fresh drinking water.

Blood samples $(5 \mathrm{~mL})$ were collected from the jugular vein in heparinised vacutainers at 7.00 am before any feed had been offered to the experimental animals on days $15,30(1 \mathrm{Mo}), 60(2$ Mo), 90 (3 Mo), 120 (4 Mo), and 150 (5 Mo). Some of the blood samples were kept for molecular study, and another portion was subjected to centrifugation (3000 rpm for $30 \mathrm{~min}$ ) for separation of plasma.

Measurement of body weight gain. The weights of the new born kids were measured as soon as the kids were cleaned and dried immediately after birth. Subsequently, the body weight of each animal was recorded as per schedule in the morning before feeding and watering. Body weight was recorded by making the animals stand individually on the weighing machine (Balance Avery, Bombay, India). Body weight and weight gain were expressed respectively in $\mathrm{Kg}$ and gram. 
S. Perveen et al.: Expression profile of growth hormone receptor, insulin like growth factor receptor and leptin genes, with associated blood bio-chemicals and endocrines profiles in black Bengal kids (Capra hircus)

Measurement of blood biochemical parameters (Blood glucose, AST and ALT). Blood glucose, AST and ALT were measured using commercially available kits specific for goats (Ecoline-Merck diagnostic kit, Merck Specialities Pvt. Ltd., Mumbai, India).

Measurement of endocrine parameters (GH and cortisol). GH and cortisol were measured by enzyme immune assay, using the commercially available ELISA kit specific for goats (MyBioSource, Inc., San Diego, CA, USA).

Expression profile of GHR, IGFR and leptin. Total RNA was extracted from blood using the Trizol method as reported by (CHOMCZYNSKI and SACCHI, 1987). The quality of RNA was checked electrophoretically using agarose gel (1.5\%). The RNA samples with two distinct intact bands representing $18 \mathrm{~S}$ and $28 \mathrm{~S}$ subunits were purified by DNAase treatment (DNA-free ${ }^{\mathrm{TM}} \mathrm{Kit}$, Ambion), and stored in RNA storage solution (Ambion). RNA was quantified by spectrophotometry. The samples with acceptable purity (i.e. ratio 1.65-2.0) were used for reverse transcription.

First strand cDNA was prepared from $1 \mu \mathrm{g}$ of RNA using the commercially available cDNA synthesis Kit (Novagen first strand cDNA synthesis kit, La Jolla, CA, USA).

Optimum annealing temperatures for all the primers of the target (GHR, IGFR and Leptin) and housekeeping ( $\beta$-actin) genes were standardized by gradient PCR (MyCycler, Bio-Rad Lab. Inc., USA) of $47-59{ }^{\circ} \mathrm{C}$ temperature range. The single bands of the expected sizes for all the genes at $55^{\circ} \mathrm{C}$ signify that the primers were highly specific to their target sequence.

Roche's Lightcycler 480 instrument was used for qPCR as per the method of PFAFFL (2001). Primers for the caprine specific target (GHR, IGFR and leptin) and housekeeping ( $\beta$-actin) genes (Table 1 ) were designed and synthesized (Sigma chemicals Co., St. Louis, Missouri, USA) so that they have an equal melting temperature range. First, strand cDNA was diluted to $1: 1$ ratio before the $\mathrm{qPCR}$ study. The master mix for qPCR for all the samples was prepared as follows: $1 \mu \mathrm{L}$ template $+5 \mu \mathrm{L}$ (2X) SYBR green mix $+0.5 \mu \mathrm{L}$ each of reverse and forward primer and $3 \mu \mathrm{L}$ nuclease free PCR grade water.

Table. 1. Primers used for gene expression studies

\begin{tabular}{|c|c|c|c|}
\hline $\begin{array}{c}\text { Sl. } \\
\text { No. }\end{array}$ & \multirow{2}{*}{ Gene } & F/R & Sequence $(5 \rightarrow 3)$ \\
\hline \multirow{2}{*}{1} & \multirow{2}{*}{ GHR } & $\mathrm{F}$ & CAGTGACATGTGCCGATGGTA \\
\cline { 3 - 4 } & & $\mathrm{R}$ & ATGTGTGATTCAGCCTCGAC \\
\hline \multirow{2}{*}{2} & \multirow{2}{*}{ LEP } & $\mathrm{F}$ & TGGAAGAGAGGAGTTCCGAG \\
\cline { 3 - 4 } & & $\mathrm{R}$ & AGGGGCAAAGGTCATTTATTTG \\
\hline \multirow{2}{*}{3} & \multirow{2}{*}{ IGFR } & $\mathrm{F}$ & GAGAAAGGGGAATTTGGTCCC \\
\cline { 3 - 4 } & & $\mathrm{R}$ & GGTGATATTCCGCAGGTTGT \\
\hline \multirow{2}{*}{4} & \multirow{2}{*}{ b-ACTIN } & $\mathrm{F}$ & CCTCAAGTACCCCATTGAGC \\
\cline { 3 - 4 } & & $\mathrm{R}$ & TGATGTCACGGACGATTTCC \\
\hline
\end{tabular}

The Light Cycler was programmed at Initial denaturation at $95^{\circ} \mathrm{C}$ for 5 minutes, then denaturation at $95{ }^{\circ} \mathrm{C}$ for 60 seconds, followed by annealing at $55^{\circ} \mathrm{C}$ for 40 seconds, and elongation at $72{ }^{\circ} \mathrm{C}$ for 60 seconds. Cycles were repeated 35 times. The final extension was at $72{ }^{\circ} \mathrm{C}$ for 7 minutes, and kept at the holding temperature of $4{ }^{\circ} \mathrm{C}$.

Calculation of the CPs (crossing points) was automatically performed by the instrument's Second Derivative Max method of absolute quantification control at each time point. The relative expression ratio was calculated as per the formula given below:

Ratio $=\left(\mathrm{E}_{\text {target }}\right)_{\text {targe }}^{\Delta \mathrm{Cp}}$ (control - sample) $/\left(\mathrm{E}_{\text {ref }}\right)_{\text {ref }}^{\Delta \mathrm{Cp}}$ (control - sample)

Where, $\mathrm{E}_{\text {target }}=$ Real Time PCR efficiency of the target gene transcript, $\mathrm{E}_{\text {ref }}=$ Real Time PCR efficiency of the reference gene transcript, $\Delta \mathrm{Cp}_{\text {target }}$ $=\mathrm{CP}$ deviation of control sample and experimental sample with target gene, $\Delta \mathrm{Cp}_{\mathrm{ref}}=\mathrm{CP}$ deviation of control sample and experimental sample with reference gene.

Statistical analysis. The experimental data were subjected to appropriate statistical analysis using the method described by SNEDECOR and COCHRAN (1967) by the IBM-SPSS software (Ver. 20.0). The General Linear Model technique repeated over age-groups and sex was considered for all variables under study. F values, if found significant, the main effect means of age group, $\mathrm{n}$ and sex were further compared by the LSD test at $5 \%$ level of significance. Pearson's correlation 
S. Perveen et al.: Expression profile of growth hormone receptor, insulin like growth factor receptor and leptin genes, with associated blood bio-chemicals and endocrines profiles in black Bengal kids (Capra hircus)

coefficients between all possible pairs of variables were calculated using sex-wise and overall sets of data.

\section{Results}

Average weight gain (gm/day). Average weight gain (gm/day) found in male and female black Bengal kids on different days of pre-pubertal growth are presented in Table 2. The average weight gain altered significantly $(\mathrm{P} \leq 0.01)$ from day 15 to 180 days. Male kids $(41.38 \pm 2.26 \mathrm{~g} /$ day $)$ gained more body weight (23\%) compared to females (33.56 \pm $2.23 \mathrm{~g} /$ day).

Table 2. Average daily weight gain (gm/day) in male and female black Bengal kids on different days of prepubertal growth

\begin{tabular}{|c|c|c|}
\hline \multirow{2}{*}{ Day } & \multicolumn{2}{|c|}{ Average daily weight gain (gm/day) } \\
\cline { 2 - 3 } & Male & Female \\
\hline 15 & $50.17 \pm 6.23$ & $40.61 \pm 3.93$ \\
\hline 30 & $34.06 \pm 4.07$ & $13.81 \pm 2.81$ \\
\hline 60 & $34.06 \pm 4.38$ & $34.06 \pm 4.13$ \\
\hline 90 & $58.17 \pm 5.57$ & $53.31 \pm 7.97$ \\
\hline 120 & $60.44 \pm 4.95$ & $36.47 \pm 4.89$ \\
\hline 150 & $26.06 \pm 2.68$ & $32.47 \pm 6.58$ \\
\hline
\end{tabular}

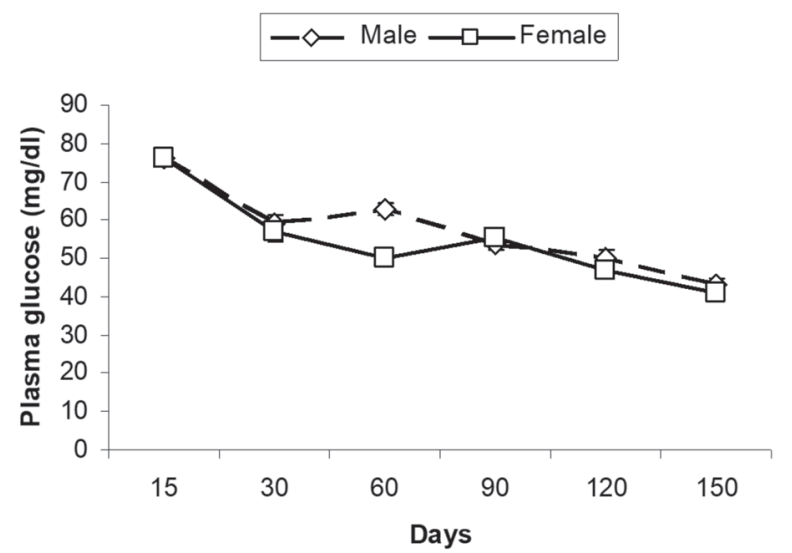

Fig. 1. Alterations in the plasma glucose levels in male and female black Bengal kids on different days of prepubertal growth. Values are expressed as mean \pm SE.

Blood glucose level. Alterations in the plasma glucose levels in male and female black Bengal kids on different days of pre-pubertal growth are presented in Fig. 1. The glucose level significantly $(\mathrm{P} \leq 0.01)$ decreased with the advancement of age, and the maximum level occurred on day 15 whereas the lowest level was at 150 days, with an overall of $54.40 \pm 1.00 \mathrm{mg} / \mathrm{dL}$ in both males and females. There was no significant difference between plasma glucose levels in male and female kids.

Plasma AST and ALT. Fig. 2 shows alterations in the AST and ALT levels in male and female black Bengal kids on different days of prepubertal growth. The overall AST and ALT levels, irrespective of sex and growth phase, were $82.73 \pm$ 1.28 and $23.43 \pm 0.55 \mathrm{IU} / \mathrm{L}$ respectively. Both AST and ALT levels increased significantly $(\mathrm{P} \leq 0.01)$ from day $15(67.01 \pm 1.97 \mathrm{IU} / \mathrm{L})$ and reached the maximum level of AST at day 90 and ALT at day 150. Our results indicated that sex has no influence on AST and ALT levels.

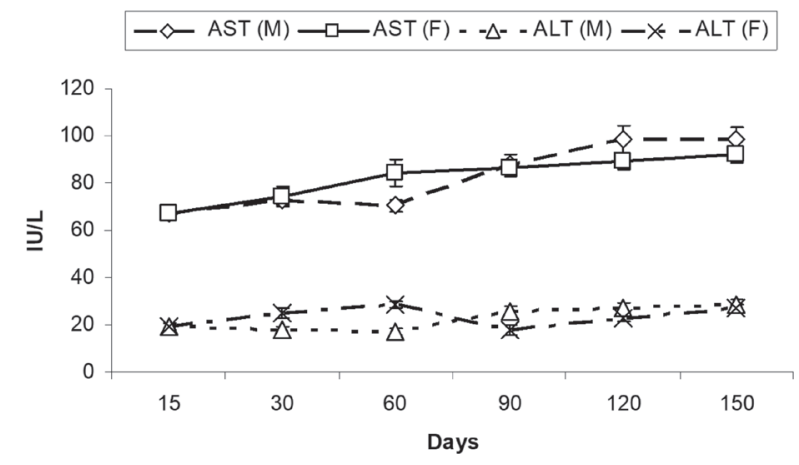

Fig. 2. Alterations in the aspartate aminotransferase (AST) and alanine aminotransferase (ALT) levels in male (M) and female (F) black Bengal kids on different days of pre-pubertal growth. Values are expressed as mean $\pm \mathrm{SE}$.

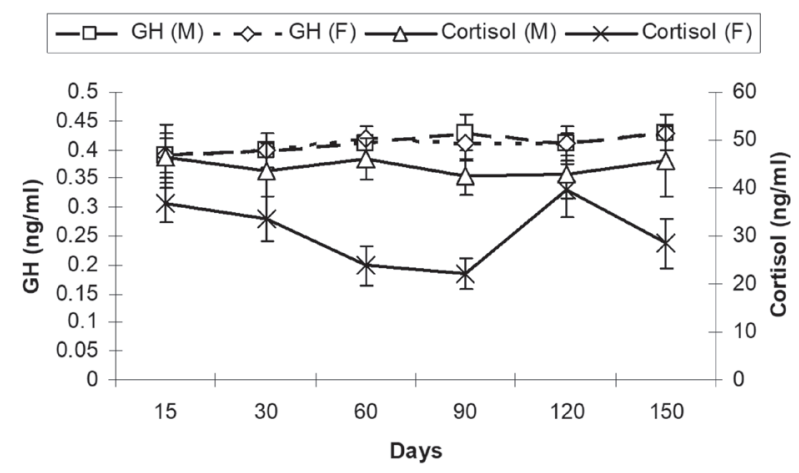

Fig. 3. Alterations in the growth hormone (GH) and cortisol level in male (M) and female (F) black Bengal kids on different days of pre-pubertal growth. Values are expressed as mean $\pm \mathrm{SE}$

$\mathrm{GH}$ and cortisol. Alterations in the growth hormone and cortisol levels in male and female black Bengal kids on different days of pre-pubertal 
S. Perveen et al.: Expression profile of growth hormone receptor, insulin like growth factor receptor and leptin genes, with associated blood bio-chemicals and endocrines profiles in black Bengal kids (Capra hircus)

growth are presented in Fig. 3. The growth hormone increased significantly $(\mathrm{P} \leq 0.01)$ from day 15 to 180 days, and cortisol level declined with the advancement of age, and was lowest at 90 days in both sexes. The overall levels of GH and cortisol were $0.41 \pm 0.01$ and $38.12 \pm 1.45$ respectively. Sex had no significant influence on GH and cortisol levels.

Table 3. Correlation coefficients between blood glucose, aspartate aminotransferase (AST), alanine aminotransferase (ALT), growth hormone (GH) and cortisol in male black Bengal kids during the prepubertal growth stage

\begin{tabular}{|l|c|c|c|c|}
\hline & $\begin{array}{c}\text { Blood } \\
\text { glucose }\end{array}$ & AST & ALT & $\begin{array}{c}\text { Growth } \\
\text { hormone }\end{array}$ \\
\hline AST & $-0.314^{* *}$ & & & \\
\hline ALT & -0.126 & $0.792^{* *}$ & & \\
\hline $\begin{array}{l}\text { Growth } \\
\text { hormone }\end{array}$ & $0.274 *$ & $0.468^{* *}$ & $0.687 * *$ & \\
\hline Cortisol & $0.248^{*}$ & $0.291 * *$ & $0.430^{* *}$ & $0.529 * *$ \\
\hline
\end{tabular}

** $\mathrm{P} \leq 0.01 * \mathrm{P} \leq 0.05$

Table 4. Correlation coefficients between blood glucose, aspartate aminotransferase (AST), alanine aminotransferase (ALT), growth hormone (GH) and cortisol in female black Bengal kids during the prepubertal growth stage

\begin{tabular}{|l|c|c|c|c|}
\hline & $\begin{array}{c}\text { Blood } \\
\text { glucose }\end{array}$ & AST & ALT & $\begin{array}{c}\text { Growth } \\
\text { hormone }\end{array}$ \\
\hline AST & $-0.265^{*}$ & & & \\
\hline ALT & 0.016 & $0.625^{* *}$ & & \\
\hline $\begin{array}{l}\text { Growth } \\
\text { hormone }\end{array}$ & $0.244^{*}$ & $0.537^{* *}$ & $0.715^{* *}$ & \\
\hline Cortisol & 0.213 & $0.354^{* *}$ & $0.503^{* *}$ & $0.607^{* *}$ \\
\hline
\end{tabular}

Correlation coefficients between blood glucose, AST, ALT, GH and cortisol. Correlation coefficients between blood glucose, AST, ALT, GH and cortisol in male and female black Bengal kids during the pre-pubertal growth stage are presented in Tables 3 and 4 respectively. In both sexes, plasma glucose level negatively $(\mathrm{P} \leq 0.01)$ correlated with AST. In males, both cortisol and GH levels were positively $(\mathrm{P} \leq 0.05)$ correlated with plasma glucose levels, but in female kids only GH showed a positive $(\mathrm{P} \leq 0.05)$ correlation with glucose levels. AST and ALT were positively $(\mathrm{P} \leq 0.01)$ correlated with growth hormone and cortisol in both male and female kids.
There was a significant positive correlation between growth hormone and cortisol in both sexes.

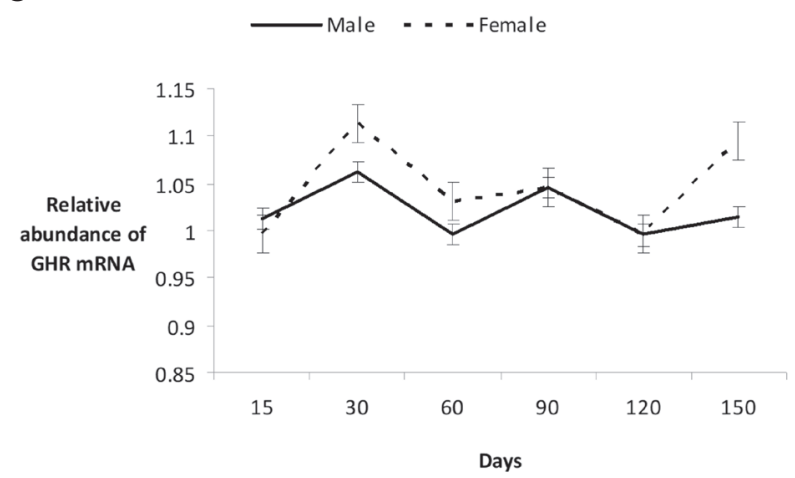

Fig. 4. Alterations in the relative abundance of growth hormone receptor (GHR) mRNA in male and female black Bengal kids on different days of pre-pubertal growth. Values are expressed as mean $\pm \mathrm{SE}$.

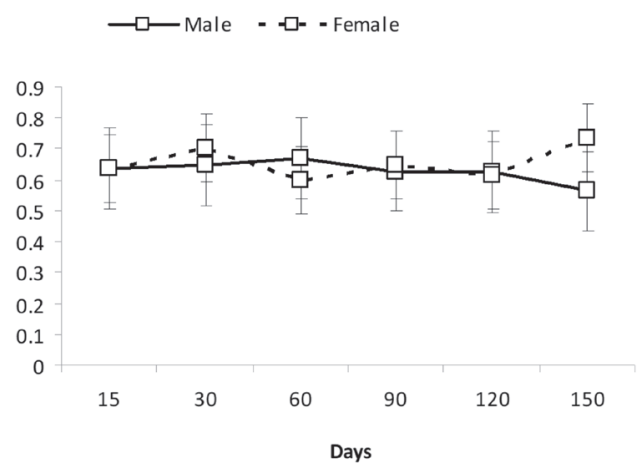

Fig. 5. Alterations in the relative abundance of insulin like growth factor receptor (IGFR) mRNA in male and female black Bengal kids on different days of prepubertal growth. Values are expressed as mean $\pm \mathrm{SE}$.

Relative abundance of GHR, IGFR and leptin $m R N A$. The relative abundance of growth hormone receptor, insulin like growth factor receptor and leptin mRNA in male and female black Bengal kids on different days of prepubertal growth phase is presented in Fig. 4, 5 and 6 respectively. The expression of all these genes varied significantly $(\mathrm{P} \leq 0.05)$ between different days of the prepubertal growth phase in both male and female kids, with the highest at day 30. Female kids had greater expression of the $\mathrm{GH}$ receptor on day $30(\mathrm{P} \leq 0.05)$, day $60(\mathrm{P} \leq 0.05)$ and day $150(\mathrm{P} \leq 0.01)$. IGFR mRNA expression was greater in female kids on day $30(\mathrm{P} \leq 0.05)$ and day $150(\mathrm{P} \leq 0.01)$, and in males on day $60(\mathrm{P} \leq 0.01)$. Leptin mRNA expression was observed more in the female kids on day 30 $(\mathrm{P} \leq 0.01)$ and day $150(\mathrm{P} \leq 0.01)$. 
S. Perveen et al.: Expression profile of growth hormone receptor, insulin like growth factor receptor and leptin genes, with associated blood bio-chemicals and endocrines profiles in black Bengal kids (Capra hircus)

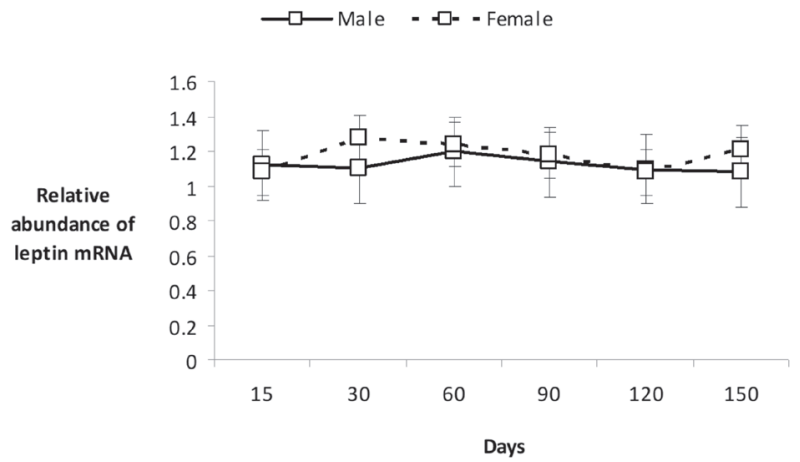

Fig. 6. Alterations in the relative abundance of leptin mRNA in male and female black Bengal kids on different days of pre-pubertal growth. Values are expressed as mean $\pm \mathrm{SE}$.

Correlation coefficients between blood glucose and expression of GHR, IGFR and Leptin. Correlation coefficients between blood glucose and expression of GHR, IGFR and Leptin in male and female black Bengal kids during the prepubertal growth stage are presented in Tables 5 and 6 respectively. GHR was positively $(\mathrm{P} \leq 0.05)$ correlated with IGFR and LEP in only female kids.

Table 5. Correlation coefficients between blood glucose and expression of growth hormone receptor (GHR) mRNA, insulin like growth factor receptor (IGFR) and Leptin (Lep) in male black Bengal kids during the prepubertal growth stage

\begin{tabular}{|l|c|c|c|}
\hline & GHR & IGFR & LEP \\
\hline IGFR & 0.053 & & \\
\hline LEP & -0.235 & 0.703 & \\
\hline $\begin{array}{l}\text { Blood } \\
\text { glucose }\end{array}$ & -0.007 & 0.675 & 0.420 \\
\hline
\end{tabular}

Table 6. Correlation coefficients between blood glucose and expression of growth hormone receptor (GHR) mRNA, insulin like growth factor receptor (IGFR) and Leptin (Lep) in female black Bengal kids during the pre-pubertal growth stage

\begin{tabular}{|c|c|c|c|}
\hline & GHR & IGFR & LEP \\
\hline IGFR & $0.834^{*}$ & & \\
\hline LEP & $0.847^{*}$ & 0.446 & \\
\hline $\begin{array}{c}\text { Blood } \\
\text { glucose }\end{array}$ & -0.374 & -0.248 & -0.376 \\
\hline
\end{tabular}

$* \mathrm{P} \leq 0.05$

\section{Discussion}

Blood glucose level have been reported to provide an index of nutritional status in goats and are influenced by the growth rate in animals (MORANT-FEHR et al., 1977). The blood glucose levels in black Bengal kids obtained in this investigation were in accordance with the earlier reports by PRADHAN (2016) and SHAIKAT et al. (2013). Declining levels of blood glucose with the advancement of age were in accordance with earlier reports in goats (UPADHAYAY and RAO, 1985; PRADHAN, 2016). In this investigation, sex had no influence on blood glucose levels, which was corroborated by earlier findings in different breeds of goats, including black Bengal (BEHERA et al., 1993; PARMAR et al., 2017) and sheep (KIRAN et al., 2012).

The values of AST and ALT were with the range reported earlier in black Bengal goats (GODARA et al., 2015) and West African Dwarf goats (ONI et al., 2012), but slightly lower than the reports by DEVRIM et al. (2015a) in Honamli and Native Hair goats. Both AST and ALT increased significantly with age in this study. Similar trends were reported earlier in goats (ELITOK, 2012; DEVRIM et al., 2015; NJIDDA et al., 2013), sheep (ANTUNOVIC et al., 2012) and cattle (MOHRI et al., 2007). Our study showed that AST and ALT did not differ significantly between male and female kids, which is in accordance with the earlier reports by GWAZE et al. (2012), but disagrees with NJIDDA et al. (2013) and TIBBO et al. (2008) who reported increased ALT in males and AST in female goats.

The values of GH in the present study were lower than the values reported in Shiba goats (HASHIZUME et al., 1999), Honamli and native hair goats (DEVRIM et al., 2015b), Tellicherry goats (SUGANYA and GOMATHY, 2009) and cross bred goats (KHAN and LUDRI, 2012). The lower GH levels in black Bengal Kids may be one of the causes of stunted growth in this breed of goats. The growth hormone increased significantly $(\mathrm{P} \leq 0.01)$ from day 15 to 180 days, which was in accordance with the earlier reports by DEVRIM et al. (2015b). In contrast, HASHIZUME et al. (1999) reported a declining trend of GH in Shiba goats. He postulated that higher levels of GH in the maternal blood is 
carried to the foetus, which increased the level of GH at birth in kids and it gradually decreased after activation of the hypothalamo-hypophyseal axis. Higher GH in neonates may be derived from milk since milk contains higher GH during the postpartum period (RONGE and BLUM, 1988). In our investigation, sex had no significant influence on $\mathrm{GH}$ level. A variable response of GH between sexes was reported earlier in goats (HODATE et al., 1985) and cattle (JOHKE et al., 1984; KELLER et al., 1979). It has also been reported that the plasma GH concentration in male lambs was significantly higher than that in castrated male lambs. In bulls, the circulating $\mathrm{GH}$ level was higher than in heifers (JOHKE et al., 1984). It has also been reported that ovariectomy induces weight gain in goats (ZHANG et al., 2014). This higher basal level of GH in males compared to females may be due to the higher sensitivity of growth hormone releasing factors in males (HODATE et al., 1985) or due to the effect of oestrogen, through modulation of GH and IGF-I (FISHER et al., 1998).

The value of cortisol in goat kids was in accordance with earlier reports by CAMARGO et al. (2010) in kids. The cortisol levels were higher at day 15, and gradually decreased from day 60 to day 90, then remained stationary. Higher levels of cortisol at birth were reported by CAMARGO et al. (2010). On the contrary, WALTMAN et al. (1991) reported that cortisol secretion levels remain stable during ageing. There is also some evidence suggesting that ageing is associated with significant activation of the hypothalamic pituitary adrenal (HPA) axis (HALBREICH et al., 1984), resulting in increased production of cortisol. In our investigation, sex had no influence over cortisol level. In contrast, DOERR and PIRKE (1976) reported that cortisol had a direct effect on gonads, and could decrease testosterone and oestrogen secretions. The different cortisol response between the sexes could be due to the binding of cortisol with transcortin and this affinity decreases with higher androgen levels (SLAUNWHITE, 1988). In contrast to these findings, HOWLAND et al. (1985) reported that increased aggressive behaviour and reduced voluntary food intake in male goats is due to an acute rise in cortisol and testosterone.
AST and ALT are the important markers for liver function in many animals, including goats (MEYER and HARVEY, 1998; MOHAMED, 2014) and are reported to be influenced by age and metabolic activity (WEIGERT et al., 1980). In this study, plasma glucose level was negatively $(\mathrm{P} \leq 0.01)$ correlated with AST. Similar findings were reported in sheep (ANOUSHEPOUR et al., 2014) and cattle (KALAITZAKIS et al., 2010). Increased AST values with decreased blood glucose may be explained by protein mobilization from muscles for gluconeogenesis (CARDOSO et al., 2008).

In this study, GH was positively correlated with blood glucose levels in both male and female kids. The hyperglycaemic effects of GH have been well documented in laboratory animals. GH increases blood glucose levels by increasing gluconeogenesis in the liver and kidneys (SCHWARZ et al., 2002; KIM et al., 2012) decreasing glycogenolysis (HOYBYE et al., 2008; CHO et al., 2006) and suppressing glucose uptake in the adipose tissue (KILGOUR et al., 1995)

The positive correlation between plasma glucose levels and cortisol in male kids was in accordance with the earlier reports by KANNAN et al. (2000) and AJION et al. (2001) in goats. Cortisol increases blood glucose levels via glycogenolysis and gluconeogenesis (BOND et al., 2004). No significant correlation was found between plasma glucose level and cortisol in females. This may be due to the fact that female animals are less excitable and stress sensitive than male animals, as indicated by lower concentrations of cortisol under the same conditions (OKEUDO and MOSS, 2005).

The positive correlation between GH, cortisol, AST and ALT obtained in this study can be explained by higher hepatic activity since both of these hormones induce gluconeogenesis in the liver (SCHWARZ et al., 2002; KIM et al., 2012; BOND et al., 2004)

The somatotropic hormone, or growth hormone, and its receptor, along with the insulinlike growth factor I axis are considered to be one of the most important regulatory systems, because of their broad range of effects and central role in growth (KATOH et al., 2008). Leptin acts as a unique nutritional signal to the growth axis, as 
high leptin levels have been observed to inhibit feed intake through binding to a specific receptor in the hypothalamus (AGARWAL et al., 2009). Growth hormone $(\mathrm{GH})$ exerts its action after binding with transmembrane receptor and leads to the activation of an intra-cellular and inter-cellular signal transduction pathway, inducing transcription of many genes, including IGF1 (ROTWEIN et al., 1994; ARGETSINGER and CARTER-SU, 1996) and leading to growth.

Novel polymorphisms of the growth hormone, growth hormone receptor genes and insulin like growth factor genes and their effects on growth traits have been reported earlier in goats (AN et al., 2011; RASOULI et al., 2017), cattle (MAJ et al., 2005) and sheep (VALEH et al., 2009). In our investigation, female kids had greater expression of GHR, IGFR and leptin compared to males, and a significant, positive correlation exists between these genes in female kids. The probable explanation for this is the higher bodyweight gain of male kids compared to females, as BERRYMAN et al. (2010) reported that growth hormone receptor gene-disrupted (GHR-/-) mice exhibited a greater percentage of body mass throughout life. This may be further validated by the study by DEVRIM et al. (2015) who reported higher levels of GH, IGF and leptin in the plasma of female goats compared to males.

Leptin acts as a unique nutritional signal to the somatotropic axis, especially in nutritionally stressed animals (ZIEBA et al., 2005) as high leptin levels have been observed to inhibit feed intake through binding to a specific receptor in the hypothalamus (AGARWAL et al., 2009). Thus, leptin gene expression is considered to be an indirect indicator of the nutritional status of the animal, and may be used as a suitable biomarker from the somatotropic axis of nutritional stress tolerance in goats (HYDER et al., 2013). Animals have a characteristic physiological ability to survive nutritional stress by altering the leptin levels required for maintaining the physiological normalcy (ZIEBA et al., 2005). Accordingly, leptin gene expression levels could act as markers for growth and feed conversion efficiency in kids, which has potential welfare applications (AGARWAL et al., 2009). BAGATH et al. (2016) also stated that GHR, LEP and IGFR mRNA transcript expression was higher in nutritionally stressed Osmanabadi goats, but in our investigation, there was no significant difference in blood glucose levels in male and female kids. So, the higher expression of leptin may be explained by body weight gain, which is significantly lower in females compared to male kids. Male goats grew more quickly, retained more nitrogen and used feed with greater efficiency than females (ASH and NORTON, 1987). The expression and secretion of leptin are associated with body fat mass (ZIEBA et al., 2005; ROCHA et al., 2001) and attributed to the levels of feed intake, and the physiological and growth stages of these animals (AGARWAL et al., 2009).

\section{Conclusion}

The present study permitted us to conclude that the lower growth rate in female kids expressed more leptin which stimulated the somatotropic axis for expression of GHR and IGFR during the prepubertal growth stage.

\section{Conflicts of interest}

The authors declare that there are no conflicts of interest.

\section{Acknowledgements}

The authors are grateful to the ICAR-Indian Veterinary Research Institute (ERS) for providing the experimental animals. The authors are also thankful to the Hon'ble Vice Chancellor of the WBUAFS for providing support to conduct the study. This research did not receive any specific grant from funding agencies in the public, commercial, or not-for-profit sectors.

\section{Referencs}

AFSAL, A., V. SEJIAN (2018): Somatotropic Axis Associated Growth Governance in Livestock. J. Vet. Sci. Res. 3, 1-3.

AGARWAL, R., P. K. ROUT, S. K. SINGH (2009): Leptin: a biomolecule for enhancing livestock productivity. Indian J. Biotechnol. 8, 169-176.

AJION, M. A., M. SAAT, I. IZULKIFLI, Y. M. GOH (2001): The effects of road transport on some physiological stress measures in goats. Asian-Aust. J. Anim. Sci. 14, 12501252.

DOI: 10.5713/ajas.2001.1250

AMIN, M. R., S. S. HUSAIN, A. B. M. M. ISLAM (2001): Reproductive peculiarities and litter weight in different genetic groups of Black Bengal goats. Asian Austral. J. Anim. 14, 297-301. 
S. Perveen et al.: Expression profile of growth hormone receptor, insulin like growth factor receptor and leptin genes, with associated blood bio-chemicals and endocrines profiles in black Bengal kids (Capra hircus)

AN, X., L. WANG, J. HOU, G. LI, Y. SONG, J. WANG, M. YANG, Y. CUI, B. CAO (2011): Novel polymorphisms of goat growth hormone and growth hormone receptor genes and their effects on growth traits. Mol. Biol. Rep. 38, 40374043.

DOI: $10.1007 / \mathrm{s} 11033-010-0522-3$

ANOUSHEPOUR, A., P. MOTTAGHIAN, M. SAKHA (2014): The comparison of some biochemical parameters in hyperketonemic and normal ewes. Euro. J. Exp. Bio. 4, 83-87.

ANTUNOVIC, Z., M. SPERANDA, D. SENCIC, J. NOVOSELEC, Z. STEINER, M. DJIDARA (2012): Influence of age on some blood parameters of lambs in organic production. Maced. J. Med. Sci.7, 11-15.

APEDA (2018): Agriculture and processed food products export development authority of India. Annual Report 2017-18. pp 1-48.

ARGETSINGER, L. S., C. CARTER-SU (1996): Growth hormone signalling mechanisms: involvement of the tyrosine kinase JAK2. Horm. Res. 45, 22-24.

DOI: $10.1159 / 000184823$

ASH, A. J., B. W. NORTON (1987): Studies with the Australian Cashmere Goat. I. Growth and digestion in male and female goats given pelleted diets varying in protein content and energy level. Aust. J. Agric. Res. 38, 957-969.

DOI: $10.1071 /$ ar9870957

BAGATH, M., V. SEJIAN, S. S. ARCHANA, G. B. MANJUNATHAREDDY, S. PARTHIPAN, S. SELVARAJU, A. MECH, G. CORBON, C. G. DAVID, J. P. RAVINDRA, R. BHATTA (2016): Effect of dietary intake on somatotrophic axiserelated geneexpression and endocrine profile in Osmanabadi goats. J. Vet. Behav. 13, 72-79.

DOI: 10.1016/j.jveb.2016.04.001

BEHERA, P.C., P. C. BISOI, B. P. MOHANTY, G. M. PANDA (1993): Clinically important serum constituents of Black Bengal goats. Ind. Vet. J. 70, 713-717.

BERRYMAN, D. E., E O. LIS, A. J. PALMER, M. U. CHUNG, J. WRIGHT-PIEKARSKI, E. LUBBERS, P. O'CONNOR, S. OKADA, J. J. KOPCHICK (2010): Two-Year Body Composition Analyses of Long-Lived GHR Null Mice. J. Gerontol. A. Biol. Sci. Med. Sci. 65A, 31-40.

DOI: $10.1093 /$ gerona/glp175

BOND, J.J., L. A. CAN, R. D. WARNER (2004): The effect of exercise stress, adrenaline injection and electrical stimulation on changes in quality attributes and proteins in Semimembranosus muscle of lamb. J. Meat Sci. 68, 469477.

DOI: 10.1016/j.meatsci.2004.05.001

CAMARGO, D. G., F. BOVInO, F. P. COSTA, F. L. F. FEITOSA (2010): Serum Cortisol levels of Newborn Goat Kids. Proceedings of the XXVI World Buiatrics Congress Nov. 14-18, Santiago de Chile, Chile.
CARDOSO, F., S. TOSTES, C. LASTA (2008): Hematological, biochemical and ruminant parameters for diagnosis of left displacement of the abomasum in dairy cows from Southern Brazil. Pesq. Agrop. Bras. Brasília. 43, 141-147.

DOI: $10.1590 / \mathrm{s} 0100-204 \times 2008000100018$

CHO, Y., M. ARIGA, Y. UCHIJIMA, K. KIMURA, J. Y. RHO, Y. FURUHATA, F. HAKUNO, K. YAMANOUCHI, M. NISHIHARA, S. TAKAHASHI (2006): The novel roles of liver for compensation of insulin resistance in human growth hormone transgenic rats. Endocrinology. 147, 5374-5384.

DOI: $10.1210 /$ en.2006-0518

CHOMCZYNSKI P., N. SACCHI (1987): Single-step method of RNA isolation by acid guanidinium thiocyanate-phenolchloroform extraction. Anal. Biochem. 162, 156-159.

DOI: 10.1016/0003-2697(87)90021-2

DEVRIM, A.K., O. ELMAZ, N. MAMAK, M. SUDAGIDAN (2015): Levels of hormones and cytokines associated with growth in Honamlı and native hair goats. Pol. J. Vet. Sci. $18,433-438$.

DOI: $10.1515 /$ pjvs-2015-0055

DEVRIM, A. K., Ö. ELMAZ, N. MAMAK, M. SUDAĞIDAN (2015a): Alterations in some clinical biochemistry values of Honamli and Native Hair goats during pubertal development. Vet. arhiv 85, 647-656.

DOI: $10.1515 /$ pjvs-2015-0055

DEVRIM, A.K., O. ELMAZ, N. MAMAK, M. SUDAGIDAN (2015b): Levels of hormones and cytokines associated with growth in Honamli and native hair goats. Pol. J. Vet. Sci. $18,433-438$.

DOI: $10.1515 /$ pjvs-2015-0055

DIXIT, A.K., B. D. SHUKLA (1995): Effficiency of different marketing channels for goats in Etawah district of Uttar Pradesh. Indian J. Agr. Eco. 50, 331.

DOERR, P., K. M. PIRKE (1976): Cortisol-Induced Suppression of Plasma Testosterone in Normal Adult Males. J. Clin. Endocr. Metab. 43, 622-629.

DOI: $10.1210 /$ jcem-43-3-622

ELITOK, B. (2012): Reference values for hematological and biochemical parameters in Saanen goats breeding in Afyonkarahisar province. Kocatepe Vet. J. 5, 7-11.

FISHER, J. S., E. M. HASSER, M. BROWN (1998): Effects of ovariectomy and hind limb unloading on skeletal muscle. J. Appl. Physiol. 85, 1316-1321.

DOI: 10.1152/jappl.1998.85.4.1316

GODARA, R. S., S. NASKAR, B. C. DAS, A. S. GODARA, M. K. GHOSH, M. MONDAL, S. A. BHAT (2015): Effect of Area Specific Mineral Supplementation on Biochemical Profile in Female Black Bengal Goats. J. Anim. Res. 5, 263-268.

DOI: $10.5958 / 2277-940 x .2015 .00045 .5$

GUPTA, N., S. P. AHLAWAT, D. KUMAR, S. C. GUPTA, A. PANDEY, G. MALIK (2007): Single nucleotide 
S. Perveen et al.: Expression profile of growth hormone receptor, insulin like growth factor receptor and leptin genes, with associated blood bio-chemicals and endocrines profiles in black Bengal kids (Capra hircus)

polymorphism in growth hormone gene exon-4 and exon-5 using PCR-SSCP in Black Bengal goats - A prolific meat breed of India. Meat Sci. 76, 658-65.

DOI: 10.1016/j.meatsci.2007.02.005

GWAZE F. R., F. CHIMONYO, M. K. DZAMA (2012): Effect of season and age on blood minerals, liver enzyme levels, and faecal egg counts in Nguni goats of South Africa. Czech. J. Anim. Sci. 57, 443-453.

DOI: $10.17221 / 6345$-cjas

HALBREICH, U., G. ASNIS, B. ZUMOFF, R. NATHAN, R. SHINDLEDECKE (1984): Effect of age and sex on cortisol secretion in depressives and normals. Psychiatry Res. 13, 221-229.

DOI: 10.1016/0165-1781(84)90037-4

HASHIZUME, T., Y. TAKAHASHI, M. NUMATA, K. SASAKI, K. UENO, K. OHTSUKI, M. KAWAI, A. ISHII (1999): Plasma Profiles of Growth Hormone, Prolactin and Insulin-like Growth Factor-I during Gestation, Lactation and the Neonatal Period in Goats. J. Reprod. Dev. 45, 273281.

DOI: $10.1262 /$ jrd. 45.273

HODATE, K., T. JOHKE, A. KAWABATA, H. FUSE, S. OHASHI, M. SHIRAKI, S. SAWA (1985): Influences of dose, age and sex on plasma growth hormone response in goats and sheep to synthetic human growth hormonereleasing factor. anim. Sci. Technol. (Jpn.). 56, 41-48. DOI: $10.2508 /$ chikusan.56.41

HOWLAND, B.E., L. M. SANFORD, W. M. PALMER (1985):Changes in serum levels of LH, FSH, prolactin, testosterone, and cortisol associated with season and mating in male pygmy goats. J. Androl. 6, 89-96.

DOI: 10.1002/j.1939-4640.1985.tb00822.x

HOYBYE, C., V. CHANDRAMOULI, S. EFENDIC, A. L. HULTING, B. R. LANDAU, W. C. SCHUMANN, A. WAJNGOT (2008): Contribution of gluconeogenesis and glycogenolysis to hepatic glucose production in acromegaly before and after pituitary microsurgery. Horm. Metab. Res. 40, 498-501.

DOI: $10.1055 / \mathrm{s}-2008-1065322$

HUSSAIN, S.S., P. HORST, A. B. M. M. ISLAM (1997): Growth performance of Black Bengal goats in different regions of Bangladesh. Asian-Australas. J. Anim. Sci.10, 491-494.

DOI: 10.5713/ajas.1997.491

HYDER, I., K. RAMESH, S. SHARMA, S. UNIYAL, V. P. YADAV, R. P. PANDA, V. P. MAURYA, G. SINGH, M. SARKAR (2013): Effect of different dietary energy levels on physiobiochemical endocrine changes and mRNA expression profile of leptin in goat (Capra hircus). Livest. Sci. 152, 63-73.

DOI: $10.1016 /$ j.livsci.2012.12.005

JOHKE, T., K. HODATE, S. OHASHI, M. SHIRAKI, S. SAWANO (1984): Growth hormone response to human pancreatic growth hormone releasing factor in cattle. Endocrinol. Jpn. 31, 55-61.

DOI: $10.1507 /$ endocrj1954.31.55

KALAITZAKIS, E., N. PANOUSIS, N. ROUBIES, N. GIADINIS, E. KALDRYMIDOU, M. GEORGIADIS, H. KARATZIAS (2010): Clinico-pathological evaluation of downer dairy cows with fatty liver. Can. Vet. J. 51, 615622.

DOI: 10.12681 /jhvms. 14902

KANNAN, G., T. H. TERRILL, B. KOUAKOU, O. S. GAZAL, S. GELAYE, E. A. AMOAH, S. SAMAKE (2000): Transportation of goats: Effects on physiological stress response and liveweight loss. J. Anim. Sci. 78, 14501457.

DOI: $10.2527 / 2000.7861450 \mathrm{x}$

KATOH, K., S. KOUNO, A. OKAZAKI, K. SUZUKI, Y. OBARA (2008): Interaction of GH polymorphism with body weight and endocrine functions in Japanese black calves. Domest. Anim. Endocrinol. 34, 25-30.

DOI: 10.1016/j.domaniend.2006.10.003

KELLER, D. G., G. H. COULTER, V. G. SMITH, G. J. KING (1979): Serum growth hormone concentration in hereford and angus calves: effects of breed, sire, sex, age, age of dam and diet. Can. J. Anim. Sci. 59, 367-373.

DOI: $10.4141 /$ cjas79-045

KEOGH, K., S. M. WATERS, A. K. KELLY, A. R. WYLIE, D. A. KENNY (2015): Effect of feed restriction and subsequent realimentation on hormones and genes of the somatotropic axis in cattle. Physiol. Genomics. 47, 264273.

DOI: 10.1152/physiolgenomics.00134.2014

KHAN, J.R., R. S. LUDRI (2012): Hormone Profile of Crossbred Goats during the Periparturient Period. Trop. Anim. Health Prod. 34, 151-162.

KILGOUR, E., S. A. BALDWIN, D. J. FLINT (1995): Divergent regulation of rat adipocyte GLUT1 and GLUT4 glucose transporters by GH. J. Endocrinol. 145, 27-33.

DOI: $10.1677 /$ joe.0.1450027

KIM, Y. D., T. LI, S. W. AHN, D. K. KIM, J. M. LEE, S. L. HWANG, Y. H. KIM, C. H. LEE, I. K. LEE, J. Y. CHIANG, H. S. CHOI (2012): Orphan nuclear receptor small heterodimer partner negatively regulates growth hormone-mediated induction of hepatic gluconeogenesis through inhibition of signal transducer and activator of transcription 5 (STAT5) transactivation. J. Biol. Chem. 287, 37098-108.

DOI: $10.1074 /$ jbc.m112.339887

KIRAN, S., A. M. BHUTTA, B. A. KHAN, S. DURRANI, M. ALI, M. ALI, F. IQBAL (2012): Effect of age and gender on some blood biochemical parameters of apparently healthy small ruminants from Southern Punjab in Pakistan. Asian Pac. J. Trop. Biomed. 2, 304-306.

DOI: $10.1016 / \mathrm{s} 2221-1691(12) 60028-8$ 
S. Perveen et al.: Expression profile of growth hormone receptor, insulin like growth factor receptor and leptin genes, with associated blood bio-chemicals and endocrines profiles in black Bengal kids (Capra hircus)

MAJ, A., C. PAREEK, M. KLAUZIÑSKA, L. ZWIERZCHOWSKI (2005): Structure and polymorphism of the 5'-noncoding regions of the bovine growth hormone receptor gene. J. Anim. Breed. Genet. 122, 414-417.

DOI: 10.1111/j.1439-0388.2005.00555.x

MEYER, D. J., J. W. HARVEY (1998): Veterinary Laboratory Medicine. Interpretation and Diagnosis. $2^{\text {nd }}$ ed., W. B. Saunders Company. Philadelphia, London, Toronto, Montreal, Sydney, Tokyo. pp. 157-187.

MOHAMED, G.A. (2014): Investigation of some enzymes level in blood and milk serum in two stages of milk yield dairy cows at Assiut city. Assiut. Vet. Med. J. 60, 110-120.

MOHRI, M., K. SHARIFI, S. EIDI (2007): Haematology and serum biochemistry of Holstein Dairy calves: Age related changes and comparison with blood composition in adults. Res. Vet. Sci. 83, 30-39.

DOI: $10.1016 /$ j.rvsc.2006.10.017

MORANT-FEHR, P., D. B. SAUVANT, A. ROUZEAN (1977): Parameters indicating nutritional status of goats. Zootechnica. 19, 195-203.

NJIDDA, A. A., I. T. HASSAN, E. A. OLATUNJI (2013): Haematological and biochemical parameters of goats of semi-arid environment fed on Natural Grazing Rangeland of Northern Nigeria. IOSR J. Agric. Vet. Sci. 3, 1-8.

DOI: $10.9790 / 2380-0320108$

OKEUDO, N. J., B. W. MOSS (2005): Serum cortisol concentration in different sex-types and slaughter weights, and its relationship with meat quality and intramuscular fatty acid profile. Pakistan J. Nutr. 4, 64-68.

DOI: $10.3923 /$ pjn.2005.64.68

ONI, A.O., O. M. ARIGBEDE, S. SOWANDE, U. Y. ANELE, O. O. ONI, C. F. I. ONWUKA, O. S. ONIFADE, O. K. YUSUF, P. A. DELE, A. Y. ADERINBOYE (2012): Haematological and serum biochemical parameters of West African Dwarf goats fed dried cassava leaves-based concentrate diets. Trop. Anim. Health Prod. 44, 483-90.

DOI: $10.1007 / \mathrm{s} 11250-011-9923-0$

PADGETT, D. A., R. GLASER (2003). How stress influences the immune response. Trends Immunol. 24, 444-448.

DOI: $10.1016 / \mathrm{s} 1471-4906(03) 00173-\mathrm{x}$

PARMAR, R., A. LATEEF, H. DAS, B. CHANDEL, H. CHAUHAN, A. BARIYA (2017): Effect of age, sex and physiological stages on biochemical profile of Mehsana goat (Capra hircus). Int. J. Livest. Res. 7, 237-244.

DOI: $10.5455 /$ ijlr.20170707055912

PFAFFL, M. W. (2001): A new mathematic model for relative quantification in real-time RT-PCR. Nucleic Acids Res. 29, 2002-2007.

DOI: $10.1093 /$ nar/29.9.e45

POLLEY, S., S. DE, S. BATABYAL, R. KAUSHIK, P. YADAVA, J. S. ARORA, S. CHATTOPADHYAY, S. PAN, B. BRAHMA, T. K. DATTA, S. L. GOSWAMI (2009): Polymorphism of fecundity genes (BMPR1B, BMP15 and
GDF9) in the Indian prolific Black Bengal goat. Small Rumin. Res. 85(2-3), 122-129

DOI: 10.1016/j.smallrumres.2009.08.004

PRADHAN, B. C. (2016): Evaluation of haematological and biochemical parameters of goats of central Odisha environment fed on natural grazing land of Odisha, India. J. Pharm. Innov. 5, 83-90.

RASOULI, S., A. ABDOLMOHAMMADI, A. ZEBARJADI, A. MOSTAFAEI (2017): Evaluation of Polymorphism in IGF-I and IGFB-3 Genes and their Relationship tith Twinning Rate and Growth Traits in Markhoz Goats. Ann. Anim. Sci. 17, 89-103.

DOI: $10.1515 /$ aoas-2016-0020

ROCHA, M., E. GRUESO, M. PUERTA (2001):The anorectic effect of oestradiol does not involve changes in plasma and cerebrospinal fluid leptin concentrations in the rat. J. Endocrinol. 171, 349-354.

DOI: $10.1677 /$ joe.0.1710349

RONGE, H., J. W. BLUM (1988): Somatomedin C and other hormones in dairy cows around parturition, in newborn calves and in milk. J. Anim. Physiol. Anim. Nutri. 60, 168176.

DOI: 10.1111/j.1439-0396.1988.tb00190.x

ROTWEIN, P., A. M. GRONOWSKI, M. J. THOMAS (1994): Rapid nuclear actions of growth hormone. Horm. Res. 42, 170-1755.

DOI: $10.1159 / 000184189$

SCHWARZ, J. M., K. MULLIGAN, J. LEE, J. C. LO, M. WEN, M. A. NOOR, C. GRUNFELD, M. SCHAMBELAN (2002): Effects of recombinant human growth hormone on hepatic lipid and carbohydrate metabolism in HIV-infected patients with fat accumulation. J. Clin. Endocrinol. Metab. 87,942 .

DOI: $10.1210 /$ jcem.87.2.8391

SHAIKAT, A.H., M. M. HASSAN, S. A. KHAN, M. N. ISLAM, M. A. HOQUE, M. S. BARI, M. E. HOSSAIN (2013): Haematobiochemical profiles of indigenous goats (Capra hircus) at Chittagong, Bangladesh, Vet. World. 6, 789-793.

DOI: $10.14202 /$ vetworld.2013.789-793

SLAUNWHITE, W. R., JR. (1988): Fuel metabolism. Fundamentals of Endocrinology, p 315.Marcel Dekker, Inc., New York.

SNEDECOR, G.W., W. G. COCHRAN (1967): Statistical Methods. $8^{\text {th }}$ ed., Iowa state university, Press, USA.

SUGANYA, G., V. S. GOMATHY (2009): Hormone profile of Tellic Herry goats during periparturient period. Tamilnadu J. Vet. Anim. Sci. 5, 211-213.

TIBBO, M., Y. JIBRIL, M. WOLDEMESKEL, F. DAWO, K. ARAGAW, J. E. O. REGE (2008): Serum enzymes levels and influencing factors in three indigenous Ethiopian goat breeds. Trop. Anim. Health Prod. 40, 657-666.

DOI: $10.1007 / \mathrm{s} 11250-008-9145-2$ 
S. Perveen et al.: Expression profile of growth hormone receptor, insulin like growth factor receptor and leptin genes, with associated blood bio-chemicals and endocrines profiles in black Bengal kids (Capra hircus)

UPADHAYAY R. C., M. V. N. RAO (1985): Hematological and biochemical; constituents of blood in goats uo to oneyear age. Ind. J. Dairy Sci. 38, 168-173.

VALEH, M. V., M. TAHMOORESPOUR, M. ANSARI, M. R. NASSIRY, D. KARIMI, A. TAHERI (2009): Association of growth traits with SSCP polymorphisms at the Growth Hormone Receptor (GHR) and Growth Hormone Releasing Hormone Receptor (GHRHR) genes in the Baluchi sheep. J. Anim. Vet. Adv. 8, 1063-1069.

DOI: $10.1038 /$ scibx.2011.255

WALTMAN, C., M. R. BLACKMAN, G. P. CHROUSOS, C. RIEMANN, S. M. HARMAN (1991): Spontaneous and glucocorticoid-inhibited adrenocorticotropic hormone and cortisol secretion are similar in healthy young and old men. J. Clin. Endocrinol. Metab. 73, 495-502.

DOI: $10.1210 /$ jcem-73-3-495
WEIGERT, P., K. SCHECK, K. B. LEMMER, W. NOREISCH (1980): Laboratory diagnostic Haflinger horses and mules. Enzymaktivitäten im Serum. Tierärztl. Praxis 8, 387 (In German).

ZHANG, L., Y.-Y. WANG, M.-Z. FU, G. LI, N. AN, S.-Y. LI, Z.-Q. ZHOU (2014): The effects of ovariectomy on meat performance and expression of GH/IGF-I in young goats. Can. J. Anim. Sci. 94, 619-626.

DOI: $10.4141 /$ cjas-2014-001

ZIEBA, D.A., M. AMSTALDEN, G. L. WILLIAMS (2005): Regulatory roles of leptin in reproduction and metabolism: a comparative review. Domest. Anim. Endocrinol. 29, 166185 .

DOI: 10.1016/j.domaniend.2005.02.019

PERVEen, S., P. K. DAS, P. R. GHOSh, D. BANERJEe, J. MUKhERJEE, M. MONDAL: Profil ekspresije receptora hormona rasta (GHR), receptora čimbenika rasta sličnog inzulinu (IGFR) i gena leptina s biokemijskim i endokrinim profilom u jaradi crne bengalske koze (Capra hircus) tijekom različitih razdoblja pretpubertetskog rasta. Vet. arhiv 90, 243-254, 2020.

\section{SAŽETAK}

Cilj istraživanja bio je procijeniti profil ekspresije receptora hormona rasta (GHR), receptora čimbenika rasta sličnog inzulinu (IGFR) i gena leptina zajedno s krvnim biokemijskim pokazateljima (glukoza, aspartat-aminotransferaza AST, alanin-aminotransferaza ALT) i endokrinim pokazateljima (hormon rasta i kortizol). U tu su svrhu 15., 30., 60. , 90., 120. i 150. dan života uzeti su uzorci krvi od 25 muške i 25 ženske jaradi crne bengalske koze (Capra hircus). Muška je jarad imala veći prirast tjelesne mase u usporedbi sa ženskom. Razine glukoze i kortizola s porastom dobi znakovito su se smanjivale $(\mathrm{P} \leq 0,01)$. AST, ALT i hormon rasta znakovito su porasli $(\mathrm{P} \leq 0,01)$. Kod oba je spola razina glukoze u plazmi bila u negativnoj korelaciji $(\mathrm{P} \leq 0,01)$ s AST-om. Kod muške su jaradi kortizol i hormon rasta bili u pozitivnoj korelaciji $(\mathrm{P} \leq 0,05) \mathrm{s}$ razinama glukoze u plazmi. Samo je u ženske jaradi hormon rasta pokazao pozitivnu korelaciju $(\mathrm{P} \leq 0,05) \mathrm{s}$ razinama glukoze. Ženska je jarad imala veću ekspresiju receptora hormona rasta, mRNA IGFR i mRNA leptina 30. dan $(\mathrm{P} \leq 0,05)$ i 150. dan $(\mathrm{P} \leq 0,01)$. GHR je bio u pozitivnoj korelaciji $(\mathrm{P} \leq 0,05)$ samo s IGFR-om i leptinom u ženske jaradi. Na temelju rezultata ovoga istraživanja možemo zaključiti da niža stopa rasta u ženske jaradi dovela do veće ekspresije leptina, što je stimuliralo somatotropnu os za ekspresiju hormona rasta i IGFR-a u pretpubertetskom razdoblju.

Ključne riječi: crna bengalska koza; receptor hormona rasta; receptor IGF; geni leptina; pretpubertetski rast 